\title{
SEROPREVALENCE OF TOXOPLASMOSIS IN FORTALEZA, CEARÁ, BRAZIL
}

\author{
Luís C. REY(1) \& Isabel L.C. RAMALHO(2)
}

\section{SUMMARY}

A serological survey of Toxoplasma gondii infection in population groups in Fortaleza, Brazil, was conducted, in order to identify seroprevalence rates according to age and risk factors associated with acquired infection. A Toxoplasma IgG-antibody enzyme immunoassay (Sanofi Pasteur Diagnostics, Marnes la Coquette, France) was employed to assess the immunity. Public day-care centers and schools were randomly selected, while three large antenatal clinics and maternity units were choosen by its importance. Population groups and results of 997 blood tests were: 227 children (mean age 3.8 years), $22.8 \%$ seropositives; 584 students (mean 11.4 years), $58.4 \%$, and pregnant and postpartum women (mean 24 years), $71.5 \%$ seropositives ( $<<0.001$ ). Of 256 participants reporting close contact with cats, $59.8 \%$ were seropositive, in contrast with $51 \%$ seropositives without contact (relative risk 1.17 ; 95\% confidence interval 1.04-1.33; $\mathrm{p}=0.01$ ). Having three or more siblings at home was related to higher seroprevalence in children and students (relative risk 1.39; $95 \%$ confidence interval 1.21-1.60; $\mathrm{p}<0.01$ ). In conclusion, toxoplasmosis seroprevalence showed a rapid increase during the first ten years of life, in association with close contact with cats and larger households, probably related to inappropriate hygiene and child-care practices.

KEYWORDS: Toxoplasmosis; Seroepidemiology; Human; Brazil.

\section{INTRODUCTION}

Toxoplasma gondii (T. gondii) infection is acquired congenitally or during life span. Congenital toxoplasmosis may occur when seronegative women is infected during pregnancy. The risk of pregnant women being primarily infected with $T$. gondii is related to the general incidence of infection in the population and the infection rate in women in childbearing age ${ }^{8}$. Acute toxoplasmosis is generally acquired by oral route, mainly through the consomption of mammalian raw or undercooked meet infected with tissue cysts; fecal-oral route is caused by contamination of sporulated oocysts from cat faeces ${ }^{10}$. As only $10-20 \%$ of acute $T$. gondii infections are symptomatic, the occurrence of disease is unknown by most individuals and can be mistaken by other causes of fever, sore throat or a mononucleosis-like syndrome ${ }^{18}$, serology is essential for an accurate diagnosis. Sabin-Feldman dye test, the long standing gold standard of previous infection assessment, is a nasty and time consuming test, performed only at reference laboratories. At present, the most employed serologic tests are indirect immunofluorescence and enzyme immunoassays ${ }^{1}$.

Toxoplasmosis sero-surveys have been held in many countries. Seropositivity in France is as high as $90 \%$, while in the USA it is of $15 \%$ as a mean, varying from 3 to $70 \%$ according to population groups ${ }^{10}$. In Brazil, prevalence studies have been carried out in the southern and the Amazon region, mostly during the $70 \mathrm{~s}$ and $80 \mathrm{~s}$, targeting specific populations and using different laboratory methods ${ }^{12-15,19}$. General seroprevalence ranged from 40 to $80 \%$, with increasing levels according to age, low socioeconomic status, rural dwelling and raw meat cooking practices $^{20,21}$.

Our aim in performing a toxoplasmosis sero-survey was to provide data for an educational program, in order to prevent infection in children and women in childbearing age.

\section{MATERIALS AND METHODS}

We conducted a cross-sectional sero-survey of Toxoplasma IgG-antibodies in pre-school children, students and pregnant and postpartum women. Sample populations groups were calculated for public day-care center attendants aged 2 to $6 \mathrm{y}$, public-school children and adolescents aged 7 to $18 \mathrm{y}$, and pregnant and postpartum women from Fortaleza, assuming a $95 \%$ confidence interval of estimated seroprevalence ${ }^{10}, 5 \%$ alpha error and a design effect of 2.0. Eight large public day-care centers were randomly choosen, stratified according to eight health districts of the city. Twelve public schools in all districts were also sampled. Pregnant women were recruited while attending three major antenatal clinics in Fortaleza, and postpartum women were enrolled at the two largest urban maternity units, during daily visits in a two-week period.

All children and students enrolled were feeling and appearing healthy. Pregnant and postpartum women had no medical complaints, and were not being followed for other reasons. Written agreement were 
obtained from all participants or parents, after explanation about the study purposes and proceedings. Questionnaire forms were applied to all participants or caretakers. This protocol was approved by the Ethics Commission of the Regional Council of Medicine of Ceara.

Blood sampling was performed in vacuum tubes without anticoagulant, according to a standard technique ${ }^{17}$. After 30 min of rest, tubes were centrifuged at 2,000-5,000 rpm for $5 \mathrm{~min}$, then sera were aliquoted in two labeled vials and kept frozen at $-70^{\circ} \mathrm{C}$. All serologic proceedings were performed after field work was accomplished.

A solid phase enzyme immunoassay (EIA) for qualitative IgG-antibody (indirect Enzyme-linked Immunoassay) was employed ${ }^{22}$ (Platelia Toxo IgG, Sanofi Diagnostics Pasteur, Marnes la Coquette, France). A 1/101 diluted serum was placed into the Toxoplasma antigen-coated wells and left incubating at $37{ }^{\circ} \mathrm{C}$ for $60 \mathrm{~min}$. If present, T. gondii antibodies of the test sample should bind to the specific antigen, while unbound antibody and other serum proteins were removed by washing. The conjugate (peroxydase-labeled monoclonal antibody specific for human gamma chains) was then added to the microplate well and incubated again for $60 \mathrm{~min}$; IgG-antibody-Toxoplasma-antigen complexes attached to the microplate well and unbound conjugate were then washed. A peroxydase chromogen solution was then added, developing a color reaction, which was stopped by an acid solution. The optical density was read at $492 \mathrm{~nm}$ in a spectrophotometer and converted into $\mathrm{IU} / \mathrm{mL}$ of $T$. gondii $\mathrm{IgG}$ antibody through a standard curve. Each commercial microplate unit contained five standard control serum (Toxo $\mathrm{S} 60$ ). Results lower than $6 \mathrm{IU} / \mathrm{mL}$ were considered negative for $T$. gondii IgG antibodies and individuals as having no specific immunity, while titers $\geq 6 \mathrm{IU} / \mathrm{mL}$ were considered Toxoplasma IgG-positive ${ }^{2}$. The EIA method have shown sensitivity of $98.6 \%$ and specificity of $88.3 \%$ (92.6\% agreement) compared to Indirect Immunofluorescence ${ }^{3}$.

Data were recorded and analyzed in an IBM-compatible microcomputer using an EPI Info 6.0 software $^{7}$. Once data consistency was checked out, frequencies and seroprevalence rates were calculated. Contingency tables $(2 \times 2)$ were prepared to compare variables; Relative Risk was used to quantify cause-effect relationships between variables. Mantel Haenszel Chi square test was employed to assess statistic significance among groups. For statistic significance an alpha error lower than $5 \%$ was considered.

\section{RESULTS}

Between March and July 1997, blood samples of 997 out of 1003 individuals enrolled were proceeded for $T$. gondii IgG-antibodies according to 3 categories: 227 children in the pre-school group (range 2 to 6 years, mean $3.8 \mathrm{y}), 584$ students $(7-18 \mathrm{y}$, mean $11.4 \mathrm{y}$ ), and 185 pregnant and postpartum women (10 to $39 \mathrm{y}$, mean $24 \mathrm{y}$ ). Frequencies of seroprevalence according to the population groups are described in Table 1.

Seroprevalence according to age ranges was: 2 to 9 years: $40.0 \%$; $10-19$ y: $60.4 \%$; 20-29 y: $73.4 \%$; and 30-39 y: 70.3\%. Toxoplasma seroprevalence increased rapidly with age $(\mathrm{p}<0.0001)$, suggesting that most of the primary infection is acquired during childhood. Figure 1 shows $T$. gondii seroprevalence increase according to ages. Columns represent the number of participants by age. For day-care attendant
Table 1

Toxoplasmosis seroprevalence (IgG) among population groups in Fortaleza, Ceará, Brazil, 1997

\begin{tabular}{lccc}
\hline Population Groups & \multicolumn{3}{c}{$\begin{array}{c}\text { Seroprevalence } \\
\text { positive }\end{array}$} \\
& N & 55 & $(22.8)$ \\
\hline Pre-school children & 227 & 341 & $(58.4)$ \\
Students & 584 & 133 & $(71.5)$ \\
Delivering women & 186 & 529 & $(53.1)$ \\
Total & 997 & &
\end{tabular}

Chi square: 107.83

$\mathrm{p}$ value $<0.0001$

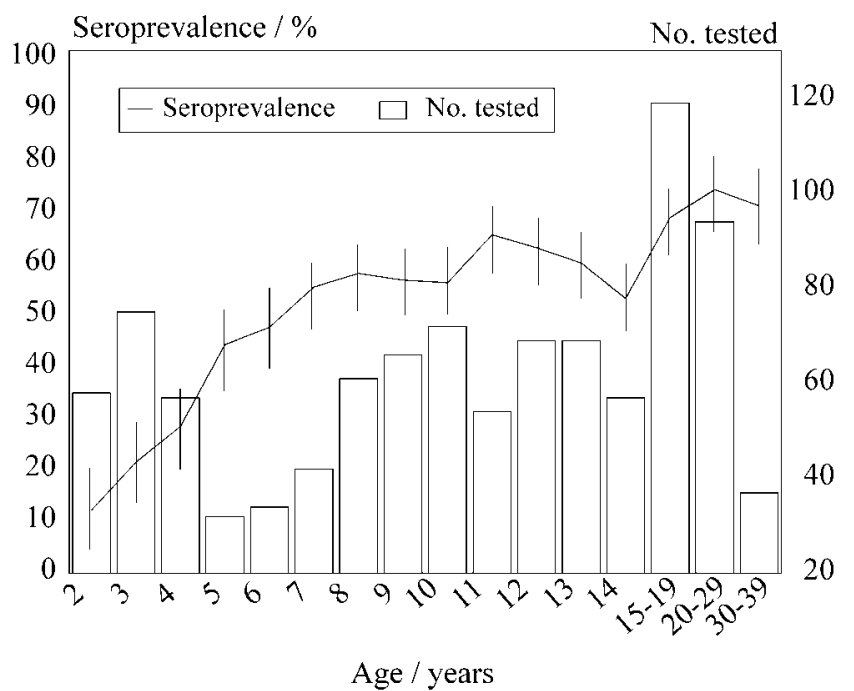

Fig. 1 - Distribution of Toxoplasma gondii seroprevalences according to age. Fortaleza, Ceará, Brazil, 1997.

No.: Number.

children, seroprevalence increased fast, with a rate of $12.1 \%$ in children aged 2 years, against $47.4 \%$ for children aged 6 . In students and women (7-39 years), the seroprevalence still increased but in a slower degree.

\section{Contact with cats}

A statistic association was found between $T$. gondii seroprevalence and close contact with cats in all groups, but not for each group alone. One fourth (256/995) of all participants referred living in close contact with cats. Of those who had cats in the household, $60 \%$ were seropositive, against $51 \%$ of those without close contact [relative risk $(\mathrm{RR})=$ $1.17,95 \%$ confidence interval $(95 \% \mathrm{CI})=1.04-1.33, \mathrm{p}=0.01]$.

\section{Previous spontaneous abortion}

Fifty-one (27.6\%) out of 185 delivering or pregnant women reported at least one spontaneous abortion prior to the present pregnancy. No statistical relationship was found between previous abortions and seroprevalence in these women. 


\section{Raw meat consumption}

Uncooked meat consumption was very rare in all study groups as pre-school children and students received only well-cooked meat as a rule at child facilities. Students 7 to 18 years old reported not to consume undercooked meat at their homes. Only ten out of 185 women answered to "appreciate" undercooked meat, although they rarely used to. Being a very rare practice, no relationship could be established between raw meat consumption and $T$. gondii IgG-seropositives in these population groups.

\section{Number of siblings}

In both pre-school and student groups, caretakers were questioned about the number of siblings in the household. Pre-school children and students aged 2 to 18 years were $40.8 \%$ seropositive $(97 / 238)$ when they had 2 siblings or less, but were $59.2 \%$ seropositive (97/238) if they had 3 to 14 siblings $(\mathrm{RR}=1.39,95 \% \mathrm{CI}=1.22-1.60, \mathrm{p}<0.001)$. This difference persisted after controlling for interaction and confounding with age and contact with cats. For the pre-school group alone, RR for toxoplasmosis seropositivity was $1.90(95 \% \mathrm{CI}=1.19-3.01$, $\mathrm{p}<0.01)$ when they had 3 or more siblings compared to a brotherhood of 2 or less.

\section{DISCUSSION}

Although we did not assess incomes or economic status, these participants are representative of low-income groups attending public health and education facilities in Fortaleza. As a cross-section design study, our data refers only to prevalence rates; incidence rates should be assessed through a seronegative cohort study. Only with this in mind are we allowed to admit an increase in seroprevalence according to ages.

The high seroprevalence level found in pre-school children is probably related to bad hygiene and crowding conditions of these facilities, where cats are often seen wandering. Despite this, the higher number of siblings was strongly related to seropositivity among day-care attendants.

An early rise in toxoplasmosis seroprevalence was evidenced, as described in other urban studies in Rio de Janeiro ${ }^{11}$ and in four regions of the city of São Paulo ${ }^{12}$. Compared to other Latin American urban surveys, our seroprevalence in students was higher than reported from Chile in 1982-1994. Among pregnant women, seroprevalence was similar to that found in La Habana, Cuba ${ }^{16}$.

Studies of toxoplasmosis seroprevalence showed a statistic correlation with close contact with cats ${ }^{6,21}$, although in our population a low relative risk was found. Other surveys failed in identifying a significant correlation between raw or undercooked consumption and increasing seroprevalence for toxoplasmosis ${ }^{6,16}$. In a comparative study conducted in Rio de Janeiro, a significant association was observed in the rural zone, but not in the urban area ${ }^{21}$. Questionnaire forms inquiring about eating preferences and cooking practices are probably inadequate to assess undercooked or raw meat ingestion in low income families. In our study raw or uncooked cooking was a very rare habit, since most families could not afford other meat than fowl. The prevalence of $T$. gondii oocysts in other domestic animals, as sheep and pork herds, and its epidemiology should also be investigated locally ${ }^{6,9}$. As a rule in child-care centers in Fortaleza, meat was always wellcooked.

A high rate report of spontaneous abortion was found in otherwise normal women; we believe many cases should be considered as induced abortion, which is an illegal although common practice in Fortaleza ${ }^{4}$. Prevalence of toxoplasmosis in pregnant/postpartum women was not related to spontaneous abortion reports, a finding also reported in $\mathrm{Cuba}^{16}$.

This study suggests that high $T$. gondii seroconversion, mostly before age 10, takes place in day-care institutions or homes through fecal-oral contamination by oocysts. Families' low income and institutional cooking rules do not favor undercooked meat consumption by youngsters. Prospective serological and parasitological studies should be carried out to confirm food and water contamination with oocysts, specially in our child-care facilities.

Since $T$. gondii infection is not interpersonally transmitted, the association between seroprevalence and household is not well understood; poor living conditions, inadequate domestic hygiene and childcare practices in larger families could be implicated in higher $T$. gondii seroprevalences. To confirm this hypothesis, comparative studies on childcare and toxoplasmosis infection are necessary, in order to provide preventive measures.

Although the number of delivering women aged 30-39 y was quite low, a small decrease in seroprevalence in the group aged 30-39 y could be related to a loss of specific Toxoplasma antibodies related to aging, which is reported with Immunofluorescence serologic methods.

\section{RESUMO}

\section{Soroprevalência da toxoplasmose em Fortaleza, Ceará, Brasil}

Foi realizado um inquérito sorológico de infecção por Toxoplasma gondii em grupos populacionais de Fortaleza, para identificar as taxas de prevalência por idades e fatores de risco associados com a infecção adquirida. Um teste imunoenzimático com anticorpos IgG antiToxoplasma (Sanofi Pasteur Diagnostics, Marnes La Coquette, França) foi utilizado para testar a imunidade. Creches e escolas públicas foram selecionadas aleatoriamente e duas maternidades e três serviços de pré-natal foram designados pela importância. A composição dos grupos e os resultados de 997 testes foram: 227 pré-escolares (média 3,8 anos), 22,8\% soropositivos; 584 estudantes (média 11,4 anos), 58,4\% positivos; gestantes e puérperas (média 24 anos), 71,5\% soropositivas ( $\mathrm{p}<0,001)$. De 256 participantes que relataram contato domiciliar com gatos, $59,8 \%$ foram soropositivos, contra $51 \%$ sem contato (risco relativo 1.17 , Intervalo de confiança de $95 \%$ 1,04-1,33, p = 0,01. Presença de três ou mais irmãos no domicílio esteve relacionada com maior soroprevalência em pré-escolares e estudantes (risco relativo 1,39; intervalo de confiança de 95\% 1,21-1,60; $\mathrm{p}<0,01)$. Em conclusão, a soroprevalência de toxoplasmose mostrou um rápido aumento durante os primeiros dez anos de vida, associada com contato domiciliar com gatos e famílias mais numerosas, provavelmente devido a higiene e cuidado das crianças inadequados. 


\section{ACKNOWLEDGMENTS}

The authors thank Dr. Edvaldo Sousa and Dr. Bart Wolf for reviewing the manuscript.

\section{REFERENCES}

1. AMERICAN ACADEMY OF PEDIATRICS - Toxoplasmosis. In: Peter, G., ed. Red Book: report of the Committee on Infectious Diseases. 24. ed. Elk Grove Village IL, American Academy of Pediatrics, 1997. p. 531-535.

2. BALSARI, A.; POLI, G.; MOLINA, V. et al. - ELISA for toxoplasma antibody detection: a comparison with other serodiagnostic tests. J. clin. Path., 33: 640-643, 1980.

3. BULLOCK, S.L. \& WALLS, K.W. - Evaluation of some of the parameters of the enzyme-linked immunospecific assay. J. infect. Dis., 136: S279-S285, 1977.

4. COELHO, H.L.; TEIXEIRA, A.C.; SANTOS, A.P. et al. - Misoprostol and illegal abortion in Fortaleza, Brazil. Lancet, 341: 1261-1263, 1993.

5. CONTRERAS, M.C.; SCHENONE, H.; SALINAS, P. et al. - Seroepidemiology of human toxoplasmosis in Chile. Rev. Inst. Med. trop. S. Paulo, 78: 431-435, 1996.

6. DE CAMARGO, M.C.; ANTUNES, C.M. \& CHIARI, C.A. - Epidemiologia da infecção por Toxoplasma gondii no município de Ribeirão das Neves, MG. I. Importância dos animais domésticos como fonte de infecção pelo T. gondii em humanos. Rev. Soc. bras. Med. trop., 28: 211-214, 1995.

7. DEAN, A.G.; DEAN, J.A.; COULOMBIER, D. et al. - Epi Info, version 6: a word-processing, database, and statistics program for public health on IBM-compatible microcomputers. Atlanta, Centers for Disease Control and Prevention, 1995.

8. DESMONDS, G. \& COUVREUR, J. - Congenital toxoplasmosis. A prospective study of 378 pregnancies. New Engl. J. Med., 290: 1110-1116, 1974.

9. FERRARONI, J.J. \& MARZOCHI, M.C. - Prevalence of Toxoplasma gondii infection in domestic and wild animals, and human groups of the Amazonas region. Mem. Inst. Oswaldo Cruz, 75: 99-109, 1980.

10. FRENKEL, J.K. - Toxoplasmose. In: Veronesi, R. - Doenças infecciosas e parasitárias. 8. ed. Rio de Janeiro, Guanabara Koogan, 1991. p. 734-749.

11. GOMES, U.A.; TERUEL, J.R.; FERRIOLI-FILHO, F. \& NOGUEIRA, J.L. - Estudo comparativo das frequiências de infecção por Toxoplasma gondii nas zonas urbana e rural. Rev. Inst. Med. trop. S. Paulo, 17: 355-360, 1975.
12. GUIMARÃES, A.C.; KAWARABAYASHI, M.; BORGES, M.M.; TOLEZANO, J.E. \& ANDRADE JR., H.F. - Regional variation in toxoplasmosis seronegativity in the São Paulo metropolitan region. Rev. Inst. Med. trop. S. Paulo, 35: 479-483, 1993.

13. KIRCHNER, E. \& COTRIM, J.X. - Immunological response to toxoplasmosis in population groups of the state of São Paulo, Brazil, as evaluated by the distribution of serum titers in the dye-test. Rev. Inst. Med. trop. S. Paulo, 14: 33-50, 1972.

14. LESER, P.G.; CAMARGO, M.E. \& BARUZZI, R. - Toxoplasmosis serologic tests in Brazilian indians (Kren-akorore) of recent contact with civilized man. Rev. Inst. Med. trop. S. Paulo, 19: 232-236, 1977.

15. LOVELACE, J.K.; MORAES, M.A. \& HAGERBY, E. - Toxoplasmosis among the Ticuna Indians in the state of Amazonas, Brazil. Trop. geogr. Med., 30: 295-300, 1978.

16. MARTINEZ-SANCHEZ, R.; BACALLAO-GORDO, R.; ALBERTI-AMADOR, E. et al. - Prevalencia de infección toxoplásmica en gestantes de la provincia de La Habana. Rev. Inst. Med. trop. S. Paulo, 36: 445-450, 1994.

17. NATIONAL COMMITTEE FOR CLINICAL LABORATORY STANDARDS - Approved standard-procedures for the collection of diagnostic blood specimens by venipuncture. 3. ed. Villanova PA, NCCLS, 1991. p. H3-A3.

18. PANNUTI, C.S.; CARVALHO, R.; EVANS, A.S. et al. - A prospective clinical study of the mononucleosis syndrome in a developing country. Int. J. Epidem., 9: 349-353, 1980.

19. RICCIARDI, I.D.; SABROZA, P.C.; SANDOVAL, E.D. \& MAYRINK, W. - Seroepidemiological study on the prevalence of human toxoplasmosis in Brazil. Rev. Microbiol. (S. Paulo), 9: 181-187, 1978.

20. RICCIARDI, I.D.; SANDOVAL, E.F. \& MAYRINK, W. - Preliminary notes on the prevalence of human toxoplasmosis in Brazil. Trans. roy. Soc. trop. Med. Hyg., 69: $516-517,1975$

21. SOUZA, W.J.; COUTINHO, S.G.; LOPES, C.W. et al. - Epidemiological aspects of toxoplasmosis in schoolchildren residing in localities with urban or rural characteristics within the city of Rio de Janeiro, Brazil. Mem. Inst. Oswaldo Cruz, 82: 475-482, 1987.

22. WALLS, K.W.; BULLOCK, S.L. \& ENGLISH, D.K. - Use of the enzyme-linked immunosorbent assay (ELISA) and its microadaptation for the serodiagnosis of toxoplasmosis. J. clin. Microbiol., 5: 273-277, 1977.

Received: 08 December 1998

Accepted: 14 April 1999 